\title{
Polysynaptic Regulation of Glutamate Receptors and Mitochondrial Enzyme Activities in the Basal Ganglia of Rats with Unilateral Dopamine Depletion
}

\author{
Richard H. P. Porter, ${ }^{1}$ James G. Greene, ${ }^{2}$ Donald S. Higgins, Jr., ${ }^{1}$ and J. Timothy Greenamyre ${ }^{1,2,3}$ \\ Departments of 'Neurology, ${ }^{2}$ Neurobiology and Anatomy, and ${ }^{3}$ Pharmacology, University of Rochester Medical Center, \\ Rochester, New York 14642
}

After nigrostriatal dopaminergic denervation, the output nuclei of the basal ganglia, the medial globus pallidus and substantia nigra pars reticulata (Snr), become overactive, in part, because of increased activity of excitatory afferents from the subthalamic nucleus (STN). Because STN uses glutamate as a transmitter, we examined whether there are regulatory changes in glutamate receptor binding in the basal ganglia. Rats received unilateral 6-hydroxydopamine lesions of the medial forebrain bundle and substantia nigra pars compacta that were confirmed by apomorphine-induced rotation and ${ }^{3} \mathrm{H}-\mathrm{GBR}-12935$ binding. As an indirect index of relative synaptic activity, succinate dehydrogenase and cytochrome oxidase activities were assayed histochemically in sections adjacent to those used for receptor binding. There were increases in enzymatic activity in entopeduncular nucleus (EP; the rodent homolog of medial globus pallidus), SNr, and globus pallidus (GP, the rodent homolog of lateral globus pallidus) in the lesioned hemisphere, suggesting increased synaptic activity, perhaps due to increased firing of the STN. Ipsilateral to the lesion, and postsynaptic to the STN, there were profound decreases in the binding of ${ }^{3} \mathrm{H}$-AMPA ( $\alpha$-amino-3-hydroxy-5-methylisoxazole propionic acid) in EP and SNr (45\% and $30 \%$, respectively); there were no alterations in the striatum, globus pallidus, or STN, and binding throughout the unlesioned hemisphere was equivalent to that in unlesioned control animals. In contrast, ${ }^{3} \mathrm{H}-\mathrm{MK}-\mathbf{8 0 1}$ binding to the NMDA receptor ion channel was not reduced in SNr, and was too low to be measured reliably in EP and STN. ${ }^{3} \mathrm{H}-\mathrm{MK}-801$ binding was reduced by $6 \%$ in striatum and $39 \%$ in globus pallidus. Compared to animals that did not receive lesions, there were $>\mathbf{3 0} \%$ bilateral reductions in striatal binding, which were larger ipsilateral to the lesion. Our results suggest that the alterations in basal ganglia circuitry associated with nigrostriatal dopamine depletion are reflected in (1) changes in succinate dehydrogenase and cytochrome oxidase activities, (2) downregu-

\footnotetext{
Received Apr. 8, 1994; May 17, 1994; May 26, 1994.

This work was supported by the American Parkinson Disease Association, the Hope A. Geoghegan Fund, the Gustavus and Louise Pfeiffer Foundation, and U.S. Public Health Service Grants NS01487 (J.T.G.), F30 MH10512 (J.G.G.), and T32 AG107 (D.S.H.).

Correspondence should be addressed to J. Timothy Greenamyre, M.D., Ph.D., Department of Neurology, University of Rochester Medical Center, 601 Elmwood Avenue, Box 673, Rochester, NY 14642.

Copyright (C) 1994 Society for Neuroscience $0270-6474 / 94 / 147192-08 \$ 05.00 / 0$
}

lation of AMPA receptors in EP and $\mathrm{SNr}$, and (3) bilateral reductions in striatal NMDA receptors.

[Key words: AMPA receptor, autoradiography, cytochrome oxidase, excitatory amino acids, 6-hydroxydopamine, NMDA receptor, Parkinson's disease, succinate dehydrogenase]

Recent models of basal ganglia circuitry have emphasized the concept that these nuclei are components of a corticobasal ganglionic-thalamo-cortical loop (Albin et al., 1989b; Crossman, 1989; Klockgether and Turski, 1989; DeLong, 1990). The striatum receives excitatory glutamatergic input from all regions of cerebral cortex (Kemp and Powell, 1970) and a dense dopaminergic input from substantia nigra pars compacta (SNc) (Moore et al., 1971). The striatum projects directly to the output nuclei of the basal ganglia, the medial segment of globus pallidus (MGP), and the substantia nigra pars reticulata (SNr) (Albin et al., 1989b; Crossman, 1989; Klockgether and Turski, 1989; DeLong, 1990). The striatum also projects to MGP and SNr indirectly via the lateral segment of the globus pallidus (LGP) and subthalamic nucleus (STN) (Albin et al., 1989b; Crossman, 1989; Klockgether and Turski, 1989; DeLong, 1990). Both the direct and indirect striatal projections use the inhibitory amino acid GABA (and colocalized neuropeptides) as their transmitters (Albin et al., 1989b). The LGP projection to STN is also GABAergic. In contrast, the pathways from STN to MGP and SNr are excitatory and glutamatergic (Albin et al., 1989a; Smith and Parent, 1989; Robledo and Feger, 1990; Brotchie and Crossman, 1991). Thus, the activity of the basal ganglia output nuclei, MGP and $\mathrm{SNr}$, is regulated both by inhibitory GABAergic input from striatum and excitatory, glutamatergic input from STN. The MGP and SNr projections to ventrolateral thalamus (VL) are GABAergic and reduce thalamocortical feedback, which is excitatory and probably glutamatergic (Albin et al., 1989b).

As a result of the dopaminergic denervation of the striatum in animal models of Parkinson's disease (PD), there are complex changes in the functional circuitry of the basal ganglia (Albin et al., 1989b; Crossman, 1989; Klockgether and Turski, 1989; DeI ong, 1990). Striatal GABAergic neurons projecting directly to MGP and $\mathrm{SNr}$ become underactive (Crossman, 1989). Thus, there is less inhibition of the output nuclei of the basal ganglia (MGP and SNr). In addition, striatal GABAergic neurons projecting to LGP become overactive (Mitchell et al., 1989). Therefore, the firing rate of the LGP GABAergic projection to STN decreases, the STN is disinhibited, and the firing rates of its excitatory, glutamatergic projections to MGP and $\mathrm{SNr}$ increase (Miller and DeLong, 1987; Mitchell et al., 1989). The activity 
of the output nuclei is therefore increased by two simultaneous, but distinct mechanisms. First, they receive less GABAergic inhibition from striatum, and second, they receive increased excitatory input from STN. As a result of the overactivity of the GABAergic projections from MGP and $\mathrm{SNr}$, neurons of the ventrolateral thalamus that project to cortex become underactive. It is believed that this decreased thalamocortical feedback underlies many of the clinical manifestations of PD (Albin et al., 1989b; Crossman, 1989; Klockgether and Turski, 1989; DeLong, 1990).

There is anatomical, biochemical, and electrophysiological evidence that the projections from STN to $\mathrm{SNr}$ and MGP are glutamatergic (Albin et al., 1989a; Smith and Parent, 1989; Robledo and Feger, 1990; Brotchie and Crossman, 1991). Neurons of the STN show selective glutamate-like immunoreactivity, but don't stain for other transmitters (Albin et al., 1989a; Smith and Parent, 1989). In SNr, postsynaptic responses elicited by STN stimulation are blocked by the broad-spectrum glutamate receptor antagonist kynurenic acid (Robledo and Feger, 1990). As noted, the STN becomes overactive with nigrostriatal dopaminergic denervation, but there is no direct evidence for changes in glutamatergic transmission in these regions. More proximally, in the striatum, there may also be altered glutamatergic neurotransmission in models of PD. It has been reported that with chronic blockade of $\mathrm{D}_{2}$ receptors there are increased basal levels of extracellular glutamate and increased levels of polassium-releasable glutamate in striatum (Yamamoto and Cooperman, 1993). There is also electrophysiological evidence that striatal dopamine depletion leads to increased spontaneous glutamate release in striatum (Calabresi et al., 1993).

In this study we examined basal ganglia NMDA and AMPA receptors and two mitochondrial enzymes in a rodent model of PD. We now report direct evidence of altered glutamatergic transmission in parkinsonism. Our results provide a further rationale for the use of glutamate receptor antagonists in the symptomatic treatment of PD.

\section{Materials and Methods}

6-Hydroxydopamine lesions. All experiments involving animals were performed in strict accordance with the NIH Guide for the Care and Use of Laboratory Animals and were approved by the University Committee on Animal Resources. Male Sprague-Dawley rats (150-200 gm) were anesthetized with Chlorolpent $(3.0 \mathrm{ml} / \mathrm{kg}$; chloral hydrate, 42.5 $\mathrm{mg} / \mathrm{ml}$, + sodium pentobarbital, $8.9 \mathrm{mg} / \mathrm{ml}$ ) and placed in a stereotaxic frame. Animals were lesioned on the right side by injecting $3 \mu \mathrm{l}$ of 6-hydroxydopamine (6-OHDA) $(2 \mu \mathrm{g} / \mu \mathrm{l}$ with $0.2 \mathrm{mg} / \mathrm{ml}$ ascorbate) at a rate of $1 \mu \mathrm{l} / \mathrm{min}$ using a Hamilton $10 \mu \mathrm{l}$ syringe with a 26 gauge needle at two sites: the first was in the anterior substantia nigra pars compacta (SNc) (posterior $4.8 \mathrm{~mm}$, lateral $1.7 \mathrm{~mm}$, and ventral $7.5 \mathrm{~mm}$, with respect to bregma and dura); the second was in the medial forebrain bundle (posterior $4.3 \mathrm{~mm}$, lateral $1.2 \mathrm{~mm}$, and ventral $7.5 \mathrm{~mm}$ ). Burr holes were filled with Gelfoam and wounds were clipped.

Six weeks after surgery animals were treated with apomorphine $(0.1$ $\mathrm{mg} / \mathrm{kg}$, i.p.), placed in fiberglass boxes $(40 \times 40 \mathrm{~cm})$, and attached to a transducer connected to a computer. Each full rotation through $360^{\circ}$ was registered as a count by the computer. Animals were monitored for $90 \mathrm{~min}$.

Six months after surgery animals were sacrificed; brains were rapidly removed, frozen on dry ice, and stored in a $-70^{\circ} \mathrm{C}$ freezer. Frozen coronal sections $(20 \mu \mathrm{m})$ were mounted on polylysine-coated slides and stored at $-70^{\circ} \mathrm{C}$. Sections were cut at five levels corresponding to the anterior striatum, globus pallidus (GP; the rodent homolog of the LGP), entopeduncular nucleus (EP; the rodent homolog of medial globus pallidus), STN, and SNr.

Enzyme histochemistry. For cytochrome oxidase (CO) histochemistry, slides were incubated for $90 \mathrm{~min}$ in $50 \mathrm{ml}$ of $0.1 \mathrm{M}$ phosphate buffer (pH 7.4) containing $30 \mathrm{mg}$ of 3,3'-diaminobenzidine and $5 \mathrm{mg}$ of cytochrome $c$ according to the method of Hovda et al. (1992). For succinate dehydrogenase (SDH) histochemistry, slides were incubated for $45 \mathrm{~min}$ in $50 \mathrm{ml}$ of $0.06 \mathrm{M}$ phosphate buffer ( $\mathrm{pH} \mathrm{7.0)}$ containing $20 \mathrm{mg}$ of nitro blue tetrazolium and $0.68 \mathrm{gm}$ of succinate (Kiernan, 1990). Both incubations were performed at $37^{\circ} \mathrm{C}$. The specificity of the $\mathrm{CO}$ reaction was confirmed with sodium azide, and that of SDH by malonate and 3-nitropropionic acid (data not shown). Following incubation, slides were removed to neutral, buffered paraformaldehyde for $10 \mathrm{~min}$. Sections were then rinsed with distilled water, dehydrated, and coverslipped. Enzyme activity on the lesioned (right) side relative to control (left) side ( $R: L$ ratio) was determined by densitometry using an MCID video-based image analysis system (Imaging Research, Inc., St. Catharines, Ontario, Canada). All readings were corrected for background (slide, mounting medium, coverslip, etc.) as described previously (Greene et al., 1993).

${ }^{3} H-G B R-12935$ autoradiography. Dopamine denervation of the striatum was determined autoradiographically by examination of the dopamine uptake complex by a method previously described (Richfield, 1991). Briefly, slide-mounted sections were incubated for $30 \mathrm{hr}$ at $4^{\circ} \mathrm{C}$ in $50 \mathrm{~mm}$ sodium phosphate buffer $(\mathrm{pH} 7.5)$ containing $120 \mathrm{mM} \mathrm{NaCl}$, $0.75 \mu \mathrm{M}$ trans-flupenthixol (Research Biochemicals International, $\mathrm{Na}$ tick, MA), $0.001 \%$ fatty acid-free bovine serum albumin, and $0.25 \mathrm{nM}$ ${ }^{3}$ H-GBR-12935 (DuPont-New England Nuclear, Boston, MA). Nonspecific binding was defined by $25 \mu \mathrm{M}$ mazindol (Research Biochemicals International, Natick, MA). After the incubation, sections were rinsed for $120 \mathrm{~min}$ in ice-cold buffer, and then rinsed for $15 \mathrm{sec}$ in distilled water and dried under a stream of warm air.

${ }^{3} H-A M P A$ receptor autoradiography. Slide-mounted sections were washed in $50 \mathrm{~mm}$ Tris-chloride buffer $(\mathrm{pH} \mathrm{7.4)}$ on ice for $30 \mathrm{~min}$, and were then dried. The assay was performed at $4^{\circ} \mathrm{C}$ with $5 \mathrm{nM}{ }^{3} \mathrm{H}$-AMPA (DuPont-New England Nuclear, Boston, MA) in 50 mм Tris-chloride buffer (pH 7.4) containing $100 \mathrm{mM} \mathrm{KSCN}$ and $2.5 \mathrm{~mm} \mathrm{CaCl}_{2}$ according to the method of Cha et al. (1992). Nonspecific binding was determined with $1 \mathrm{mM}$ L-glutamate. The incubation was terminated after $45 \mathrm{~min}$, and the sections received three 5 sec dips in Tris-chloride buffer before being dried.

${ }^{3} \mathrm{H}-\mathrm{MK}-801$ autoradiography. Slide-mounted sections received a 30 min wash in Tris-acetate buffer $\left(\mathrm{pH} \mathrm{7.4)}\right.$ at $4^{\circ} \mathrm{C}$. The sections were incubated at room temperature for $4 \mathrm{hr}$ at a final concentration of $5 \mathrm{nM}$ ${ }^{3}$ H-MK-801 (DuPont-New England Nuclear, Boston, MA) in the presence of $30 \mu \mathrm{M}$ glutamate and $10 \mu \mathrm{M}$ glycine in a volume of $10 \mathrm{ml}$ according to the method of Sakurai et al. (1991). Nonspecific binding was determined by $5 \mu \mathrm{M}$ MK-801 (Research Biochemicals International, Natick, MA). The assay was terminated by a $5 \mathrm{sec}$ dip in Tris-acetate buffer, followed by a 90 min wash. The sections were then dried.

Autoradiographic analysis. All autoradiographic sections were apposed to tritium-sensitive film (Hyperfilm $-{ }^{3} \mathrm{H}$, Amersham, Arlington Heights, IL) with calibrated tritium standards. Exposure times varied from 4-9 weeks, according to the ligand used. Autoradiograms were developed in Kodak D-19, fixed, and dried. The autoradiographic films were analyzed using the MCID system; all binding data were obtained from autoradiographic images.

Statistics. Side-to-side comparisons were made by two-tailed paired $t$ tests. Comparisons between control and lesioned animals were made with two-tailed unpaired $t$ tests. A $p$ value of less than 0.05 was considered significant statistically.

\section{Results}

\section{Verification of nigrostriatal lesions}

Behavioral and biochemical markers were used to confirm adequate dopaminergic denervation. Apomorphine-induced rotational behavior confirmed the unilateral lesion of the nigrostriatal dopamine system (Fig. 1A). Lesioned animals displayed robust contralateral turning (197 \pm 29 rotations $/ 90 \mathrm{~min})$ and negligible ipsilateral rotations $(3 \pm 2$ rotations $/ 90 \mathrm{~min})$. This rotational behavior was reflected biochemically by an $88.0 \pm$ $1.2 \%$ loss of ${ }^{3} \mathrm{H}-\mathrm{GBR}-12935$ binding ipsilateral to the lesion, confirming the loss of striatal dopamine innervation (Fig. $1 B$ ).

\section{Enzyme histochemistry}

The activities of $\mathrm{CO}$ and SDH were symmetric in all brain regions in unlesioned control animals, but were significantly 

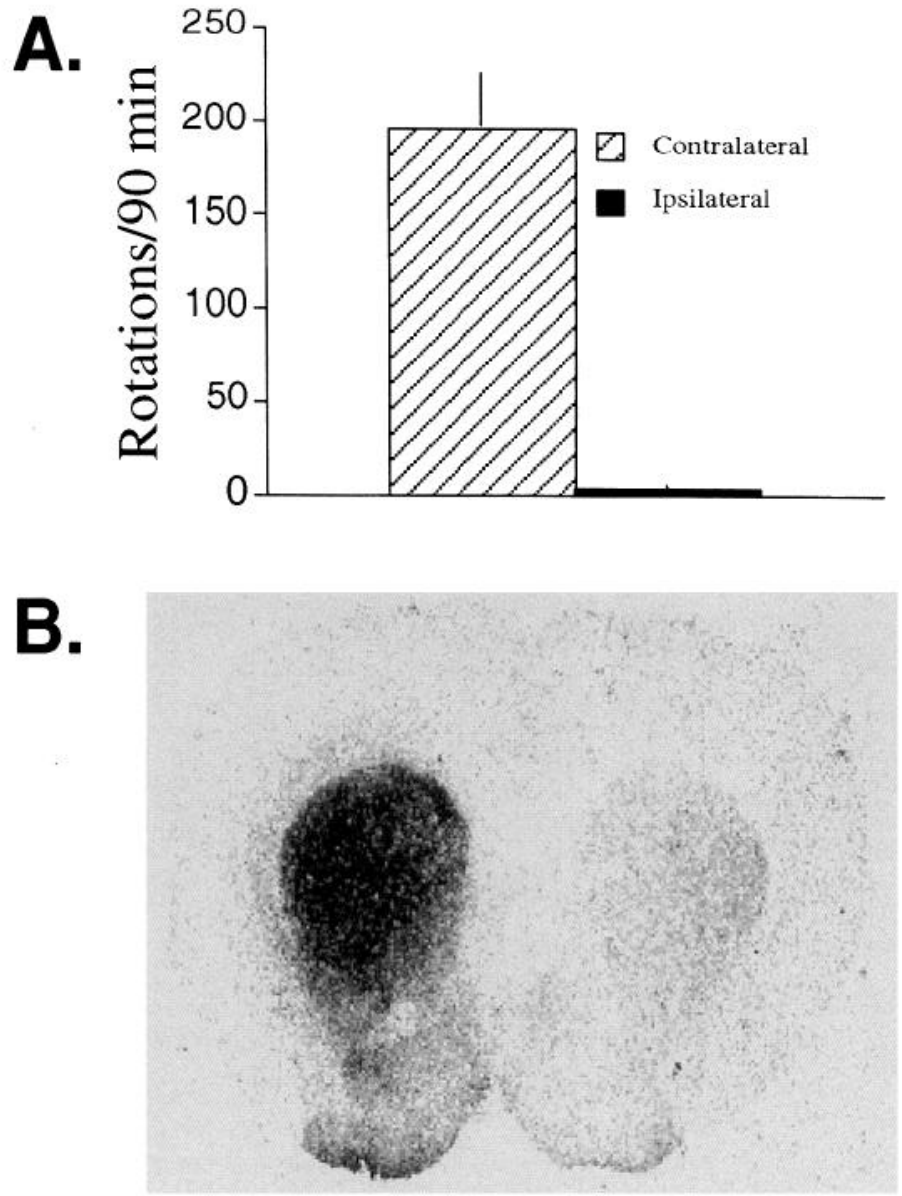

Figure 1. A, Rotational behavior induced by apomorphine $(0.1 \mathrm{mg} /$ $\mathrm{kg}$, i.p.) in the rats used in this study $(n=5)$. $B$, Autoradiogram of ${ }^{3} \mathrm{H}$ GBR-12935 binding to striatal dopamine uptake sites in a 6-OHDAlesioned rat. Note the profound loss of binding on the right, ipsilateral to the lesion. Overall, there was an $88.0 \pm 1.2 \%$ loss of binding in the lesioned animals.

increased ipsilateral to the lesion in the EP, SNr, and GP (Figs. $2,3)$. CO activity was increased by approximately $22 \%$ in the $\mathrm{EP}(p<0.05), 11 \%$ in the GP $(p<0.09)$, and $10 \%$ in the $\mathrm{SNr}$ $(p<0.01)$. SDH activity was increased by about $18 \%$ in the EP $(p<0.005), 18 \%$ in the GP $(p<0.05)$, and $30 \%$ in the $\operatorname{SNr}(p$ $<0.005)$. There were no side-to-side differences in the activity of either enzyme in the striatum or STN of lesioned animals (Fig. 2).

\section{AMPA receptor binding}

In our autoradiographic assay, virtually all ${ }^{3} \mathrm{H}$-AMPA binding was specific. Within the basal ganglia, highest levels of binding were found in striatum (Table 1). In unlesioned control animals, there were no side-to-side binding differences in any region of the basal ganglia (data not shown). Also, there were no differences between binding in the control animals and binding in the unlesioned hemisphere of 6-OHDA-lesioned animals (data not shown). In lesioned animals, ipsilateral to the dopaminergic denervation, AMPA binding was reduced by $45 \%$ in EP ( $p<$ $0.025)$ and by $30 \%$ in $\mathrm{SNr}(p<0.0025)$ (Table 1 , Figs. $3-5)$. There were no significant changes in binding in striatum, GP, or STN.
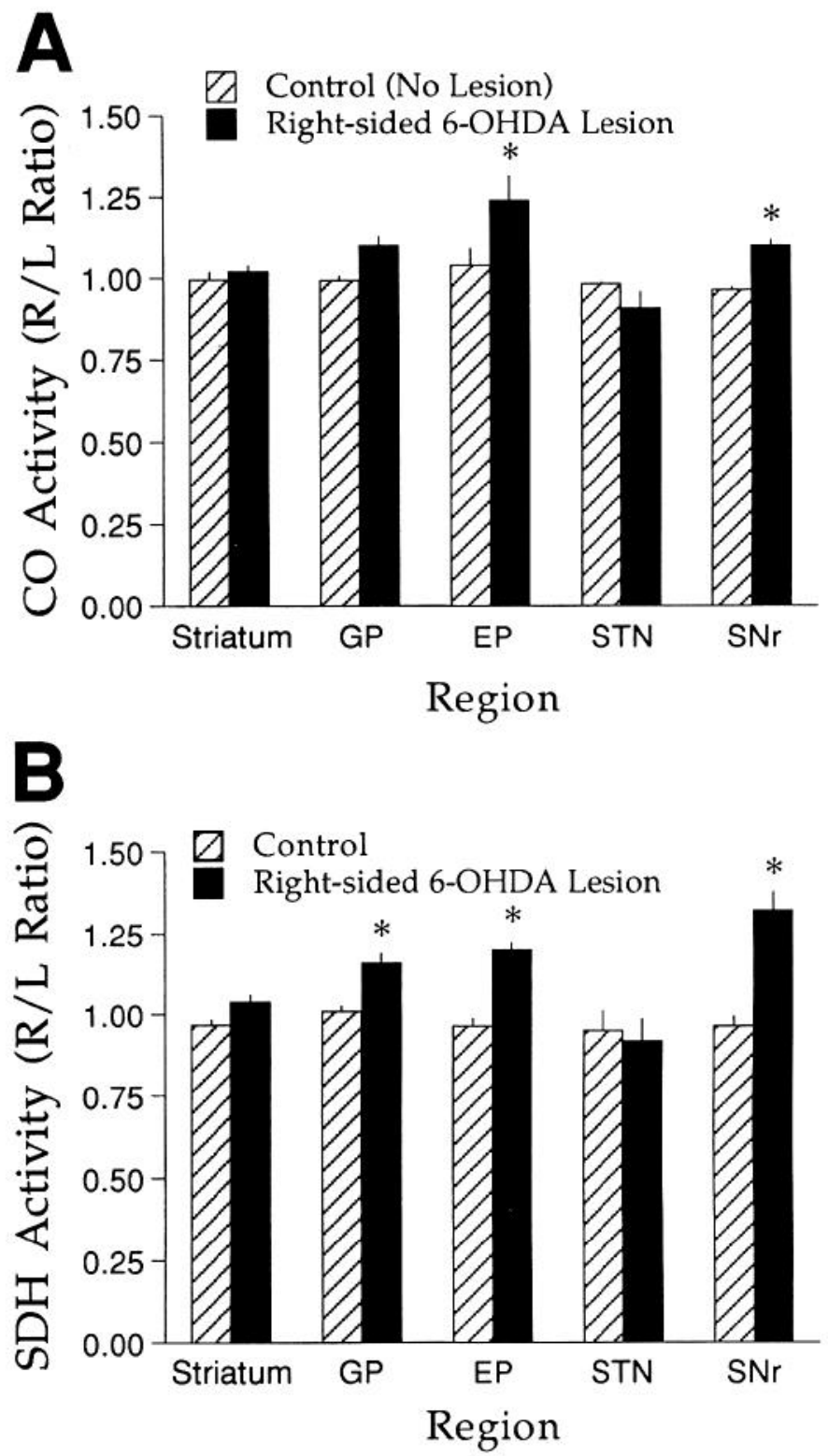

Figure 2. A, Cytochrome oxidase activity in control and 6-OHDAlesioned rats. For purposes of presentation, the data are shown as ratios of enzyme activity in the right hemisphere compared to the left hemisphere $(R / L)$. The right hemisphere of the lesioned rats was injected with 6-OHDA. Statistical analysis was performed on the raw data, not the ratios, by two-tailed, paired $t$ tests. In control animals, there were no significant side-to-side differences, but in the lesioned animals, cytochrome oxidase activity was increased in $\mathrm{EP}(p<0.05), \mathrm{SNr}(p<$ $0.01)$, and GP $(p<0.09)$. B, Succinate dehydrogenase activity in control and 6-OHDA-lesioned rats. Results are presented, and were analyzed, as above. Succinate dehydrogenase activity was increased in EP $(p<$ $0.005), \operatorname{SNr}(p<0.005)$, and GP $(p<0.05) .^{*}$, statistically significant.

\section{$M K-801$ binding}

${ }^{3} \mathrm{H}-\mathrm{MK}-801$ binding was enhanced by inclusion of saturating concentrations of glutamate and glycine in the assay, and was performed under equilibrium conditions. More than $80 \%$ of binding was specific. As with AMPA binding, highest levels of MK-801 binding in the basal ganglia were found in striatum. There were no side-to-side binding differences in the basal ganglia or other brain regions in unlesioned control animals (data not shown). Under the assay and exposure conditions used in 
Control
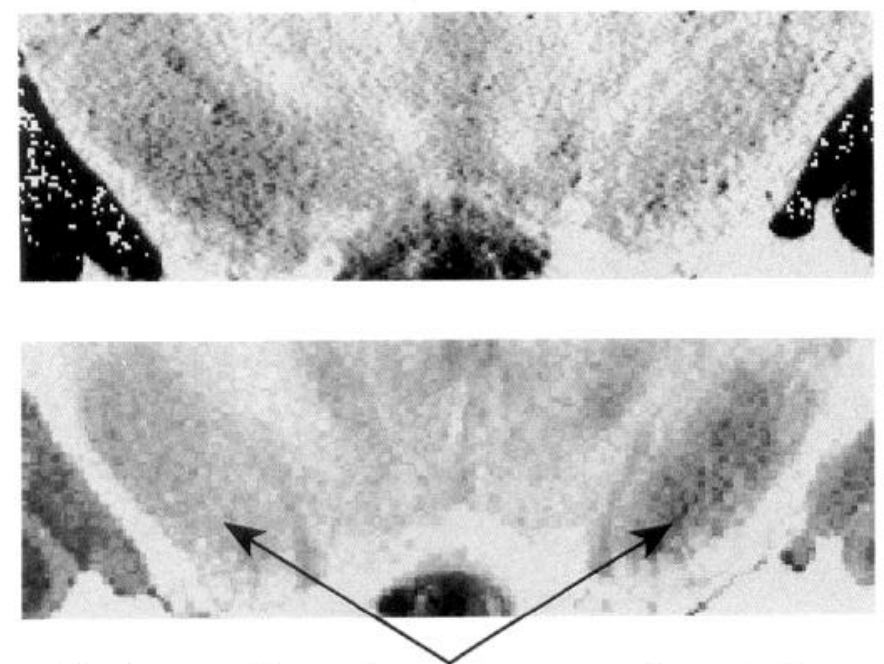

Substantia nigra pars reticulata
AMPA Binding
Succinate Dehydrogenase
Figure 3. Digitized images of AMPA receptor binding (top) and succinate dehydrogenase activity (bottom) at the level of $\mathrm{SNr}$ in a 6-OHDA-lesioned rat. There is decreased ${ }^{3} \mathrm{H}$-AMPA binding and increased succinate dehydrogenase activity in the $\mathrm{SNr}$ ipsilateral to the lesion. Thus, in SNr, AMPA receptor binding and succinate dehydrogenase activity regulate in opposite directions. these studies, levels of MK-801 binding in STN and EP were too low to be quantified reliably. Compared to unlesioned control animals, there was a $31 \%$ decrease in MK- 801 binding in the striatum contralateral to the nigrostriatal lesion $(p<0.0001)$ (Figs. 6A,7), but no changes were seen in other brain regions, including $\mathrm{GP}, \mathrm{SNr}$, stratum radiatum of $\mathrm{CA} 1$, dentate gyrus, or medial geniculate. In the lesioned animals, there was a significant $6 \%$ decrease in striatal binding ipsilateral to the lesion ( $p$ $<0.025$ ) (Table 1, Fig. $6 B$ ). Thus, there were significant bilateral reductions in striatal MK-801 binding that were greater ipsilateral to the dopamine depletion. In the lesioned animals, there was also a significant $39 \%$ decrease in binding in GP ipsilateral to the lesion $(p<0.025)$, but the small decrease in binding in $\mathrm{SNr}$ (Table 1, Fig. $6 B$ ) did not reach statistical significance, and binding was symmetric in other regions.

Table 1. ${ }^{3} \mathrm{H}-\mathrm{AMPA}$ and ${ }^{3} \mathrm{H}-\mathrm{MK}-801$ binding in rats with unilateral 6-OHDA lesions

\begin{tabular}{|c|c|c|}
\hline & ${ }^{3} \mathrm{H}$-AMPA & ${ }^{3} \mathrm{H}-\mathrm{MK}-801$ \\
\hline \multicolumn{3}{|l|}{ Striatum } \\
\hline Contralateral & $175.7 \pm 12.3$ & $82.8 \pm 2.7$ \\
\hline Ipsilateral & $167.5 \pm 10.6$ & $77.8 \pm 2.8^{*}$ \\
\hline \multicolumn{3}{|l|}{ Globus pallidus } \\
\hline Contralateral & $27.5 \pm 2.2$ & $12.5 \pm 2.0$ \\
\hline Ipsilateral & $34.7 \pm 3.2$ & $7.6 \pm 1.4^{*}$ \\
\hline \multicolumn{3}{|c|}{ Entopeduncular nucleus } \\
\hline Contralateral & $16.3 \pm 1.9$ & NA \\
\hline Ipsilateral & $9.0 \pm 2.1^{*}$ & NA \\
\hline \multicolumn{3}{|c|}{ Subthalamic nucleus } \\
\hline Contralateral & $45.8 \pm 8.2$ & NA \\
\hline Ipsilateral & $41.4 \pm 7.0$ & NA \\
\hline \multicolumn{3}{|c|}{ Substantia nigra pars reticulata } \\
\hline Contralateral & $47.5 \pm 5.0$ & $19.7 \pm 3.2$ \\
\hline Ipsilateral & $33.9 \pm 4.3^{* *}$ & $17.2 \pm 2.9$ \\
\hline
\end{tabular}

\section{Discussion}

Nigrostriatal dopaminergic denervation in animal models of PD leads to complex changes in basal ganglia circuitry (Albin et al., 1989b; Crossman, 1989; Klockgether and Turski, 1989; DeLong, 1990). Our results suggest that the alterations in basal ganglia circuitry are reflected in (1) increased cytochrome oxidase and succinate dehydrogenase activities in $\mathrm{EP}, \mathrm{SNr}$, and GP; (2) downregulation of AMPA receptor binding in EP and $\mathrm{SNr}$; and (3) bilateral reduction of striatal NMDA receptors. Together, our findings support the concept of altered glutamatergic synaptic activity in the basal ganglia in PD (Klockgether and Turski, 1989).

\section{Mitochondrial enzyme activity as a marker for synaptic activity}

Although all cells in the brain contain mitochondria and the electron transport enzymes cytochrome oxidase and succinate dehydrogenase, neurons depend on mitochondrial oxidative metabolism more than non-neuronal cell types (Wong-Riley, 1989). Consequently, mitochondria and associated enzymes are

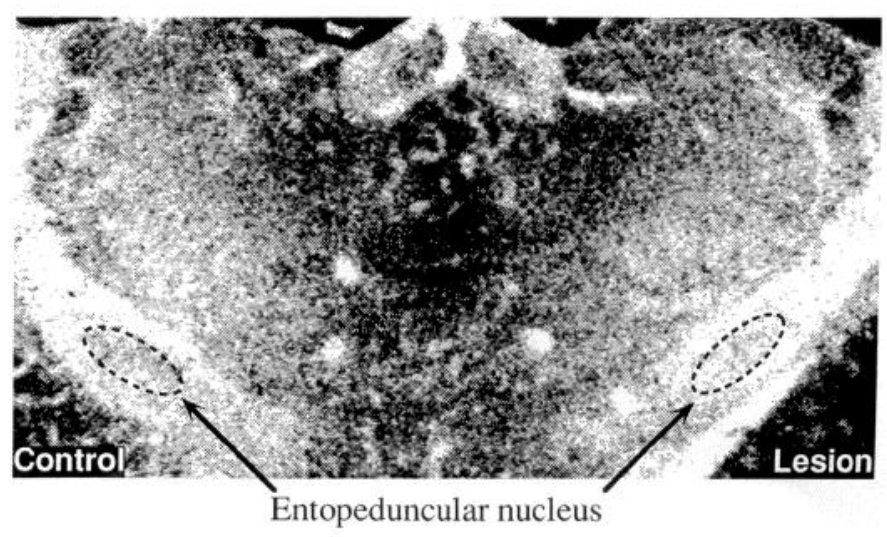

Figure 4. Digitized image of AMPA receptor binding at the level of the EP (dashed outlines). Ipsilateral to the dopamine depletion, there is a reduction of binding in EP. In the same region, there is an increase in succinate dehydrogenase and cytochrome oxidase activities (Fig. 2). 


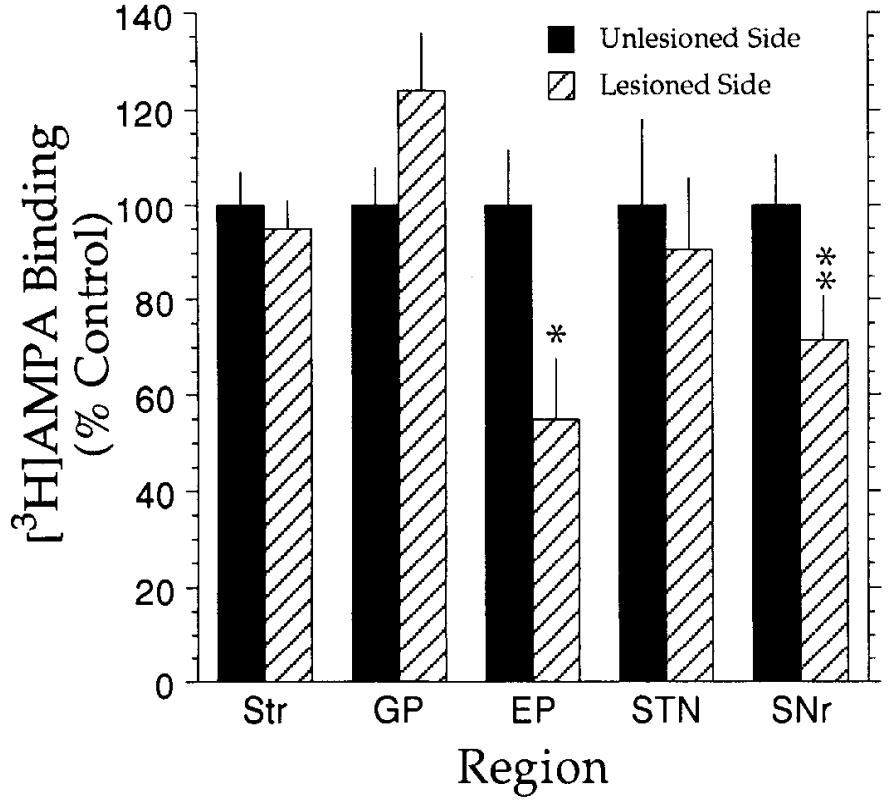

Figure 5. Histogram of AMPA receptor binding in 6-OHDA-lesioned rats. Results are expressed as percentage control binding where control values were from the unlesioned hemisphere. Absolute values are found in Table 1. Binding in the unlesioned hemisphere did not differ from that in unlesioned control animals. ${ }^{*}$, statistically significant.

highly concentrated in neurons compared to glia. Moreover, mitochondrial cnzymes arc not uniformly distributed in the brain (Wong-Riley, 1989; Greenamyre et al., 1992). To a variable degree, neuronal mitochondrial electron transport enzyme activity is regulated by regional energy demand. One of the major determinants of neuronal energy demand is maintenance of ion pump function. Changes in synaptic firing patterns alter the requirements for ion pump activity, thereby modifying energy demand and, ultimately, mitochondrial enzyme levels and activity. As documented in detail by Wong-Riley and colleagues, cytochrome oxidase activity is regulated by changes in synaptic firing patterns (see Wong-Riley, 1989, for review). Similarly, our laboratory has demonstrated that another mitochondrial electron transport enzyme, NADH:ubiquinone oxidoreductase (complex I), is also regulated by synaptic activity (D. S. Higgins and J. T. Greenamyre, unpublished observations). Thus, in some cases, mitochondrial electron transport enzyme activity can be used as an indirect index of changes in synaptic firing patterns.

With nigrostriatal dopamine depletion, it has been documented by electrophysiological and 2-deoxyglucose uptake studies that the glutamatergic STN becomes overactive (Miller and DeLong, 1987; Mitchell et al., 1989). The STN sends its major projections to MGP/EP, SNr, and GP (Ricardo, 1980). In our study, unilateral dopamine depletion was found to be associated with increased cytochrome oxidase and succinate dehydrogenase activities in the ipsilateral EP, SNr, and GP. Similar changes in succinate dehydrogenase activity were reported previously by Marshall et al. (1981). Together, these data suggest strongly that the upregulation of mitochondrial enzyme activities in EP, $\mathrm{SNr}$, and GP is a direct consequence of increased STN firing. Further support for this notion comes from the finding of simultaneous downregulation of AMPA receptors in EP and SNr. Whether the increased electron transport enzyme activities are localized in postsynaptic or presynaptic elements in $\mathrm{EP}$ and $\mathrm{SNr}$ is currently under investigation. Also, the extent to which in-
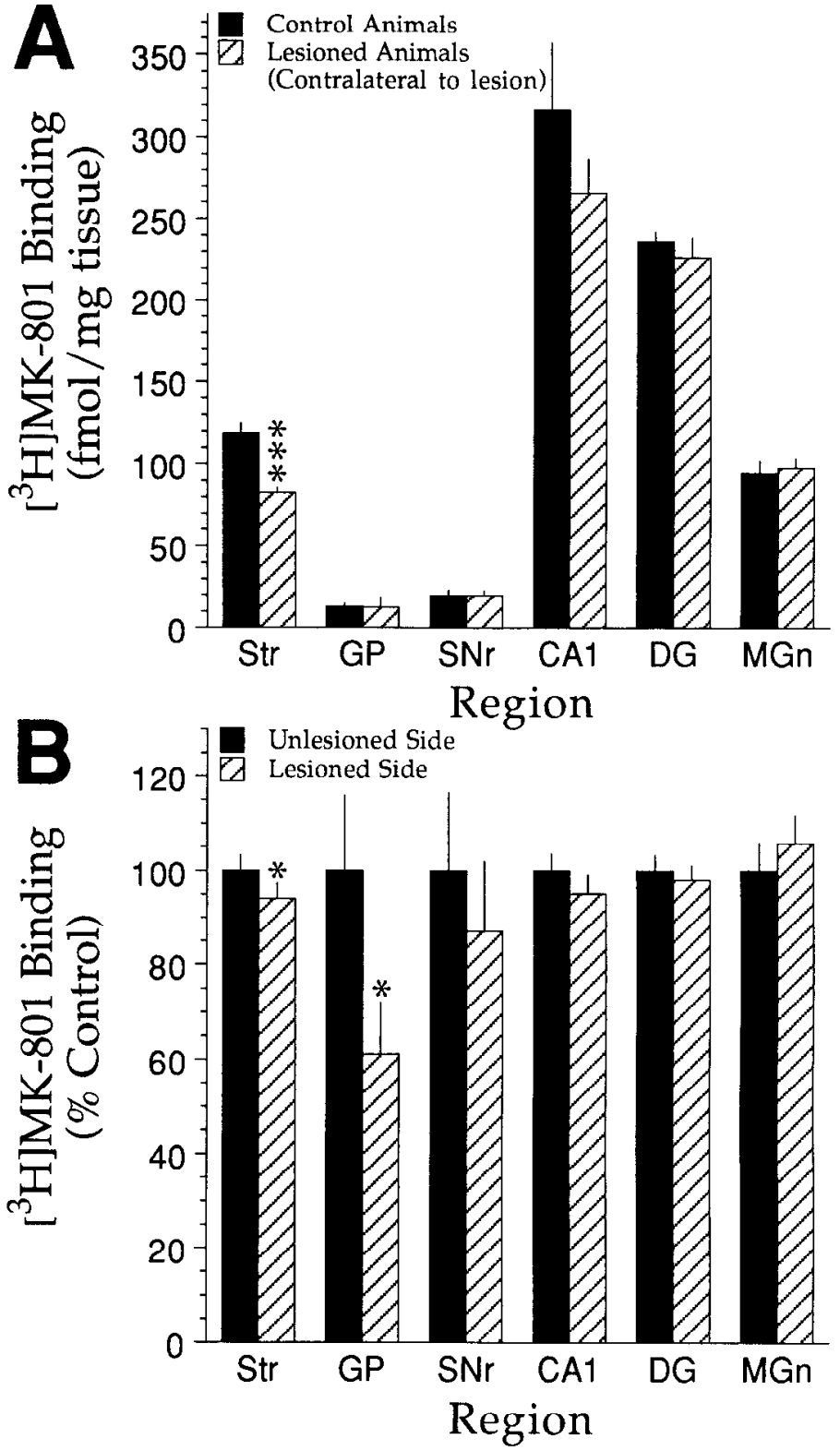

Figure 6. A, NMDA receptor hinding in control and 6-OHDA-lesioned rats. Compared to unlesioned control animals, there was a $31 \%$ reduction in striatal NMDA receptor binding in 6-OHDA-lesioned animals in the hemisphere contralateral to the dopamine depletion $(p<$ $0.0001)$; there was a further decrement ipsilateral to the lesion. Aside from striatum, binding in the unlesioned hemisphere of 6-OHDA-lesioned rats did not differ significantly from unlesioned controls. Results are expressed as $\mathrm{fmol} / \mathrm{mg}$ tissue. $B$, NMDA receptor binding in 6-OHDAlesioned animals. There was decreased MK-801 binding in striatum ( $p$ $<0.025)$ and GP $(p<0.025)$ in the hemisphere ipsilateral to the lesion relative to the contralateral hemisphere. Results are expressed as percentage control binding where control values were from the unlesioned hemisphere. *, statistically significant. $C A 1$, stratum radiatum of $\mathrm{CAl}$; $D G$, stratum moleculare of the dentate gyrus; $M G n$, medial geniculate; Str, striatum.

creased firing of neurons projecting from striatum to GP contributes to the increased mitochondrial enzyme activity seen in GP is not yet known.

\section{Glutamate receptor regulation after dopaminergic denervation}

Glutamate receptors arc found throughout the basal ganglia, but receptor autoradiographic and in situ hybridization studies in- 
dicate that the receptor subtypes are differentially distributed (Sommer et al., 1990; Moriyoshi et al., 1991; Albin et al., 1992). The highest densities of NMDA and AMPA receptors in the basal ganglia are found in striatum (Albin et al., 1992). Other regions of the basal ganglia have lower densities of glutamate receptors. When compared to NMDA receptors, AMPA receptors have a higher relative density (normalized to striatal binding) in GP (LGP), STN, EP, and SNr (Albin et al., 1992). So far, electrophysiological studies have not adequately characterized the pharmacology of glutamatergic synapses in these regions of basal ganglia. Based on receptor densities, however, it might be concluded that AMPA receptors have a larger role than NMDA receptors in motor-related synaptic transmission in MGP/EP and SNr. In support of this conclusion, Klockgether and Turski (1993) reported that microinjection of AMPA-but not NMDA-into MGP/EP or SNr induced parkinsonian rigidity in rats.

We have found downregulation of AMPA receptors-but not NMDA receptors - in $\mathrm{SNr}$ ipsilateral to the dopaminergic depletion; a similar downregulation occurs in EP. This downregulation is most likely a consequence of the overactivity of the glutamatergic afferents from STN. Moreover, after lesion of the STN, there is a selective upregulation of AMPA receptors-but not NMDA receptors - in $\mathrm{SNr}$ (Price et al., 1993) The selectivity of this receptor regulation adds support to the contention that AMPA receptors may have a more important function than NMDA receptors in synaptic transmission in the pathways from STN to EP and SNr.

Although it is likely that decreased AMPA receptor binding represents a decrease in the number of receptors, there are alternative explanations. For example, reduced receptor affinity would also cause decreased binding under the conditions of our assay. Overactivity of afferents from STN could lead to increased extracellular levels of glutamate. Despite the prewash procedure used in our binding assay, enough glutamate might be available to compete for AMPA binding sites. The EP, where the largest changes occur, is too small to perform saturation studies, but the use of AMPA receptor antibodies for immunocytochemistry and Western blot studies may clarify this issue. There is also a possibility that reduced AMPA binding is a reflection of altered AMPA receptor subunit composition. Immunocytochemistry, using subtype-specific antibodies, and in situ hybridization, using subunit-specific oligonucleotide probes, are being used to evaluate this possibility.

Within the striatum, it appears that NMDA receptors are selectively enriched in striatal projection neurons (TallaksenGreene et al., 1992). This may indicate that the major influence of glutamate on striatal projection neurons is mediated by NMDA receptors. It has been reported that injection of nontoxic doses of NMDA - but not AMPA - into the anterior striatum produces parkinsonian signs (Klockgether and Turski, 1993). In this regard, our finding of changes in striatal NMDA receptorsbut not AMPA receptors-is interesting. Others have recently reported similar changes in striatal NMDA receptors after 6-OHDA lesions (Weihmuller et al., 1993); however, unlesioned control animals were not employed in these studies, so the bilaterality of the receptor changes remains to be confirmed. After MPTP lesions in mice, a larger but transient loss of NMDA receptors was also reported (Wüllner et al., 1993).

The reduction in NMDA receptors may be a result of transsynaptic changes that cause elevated levels of striatal glutamate. Chronic blockade of $\mathrm{D}_{2}$ receptors leads to elevated basal levels

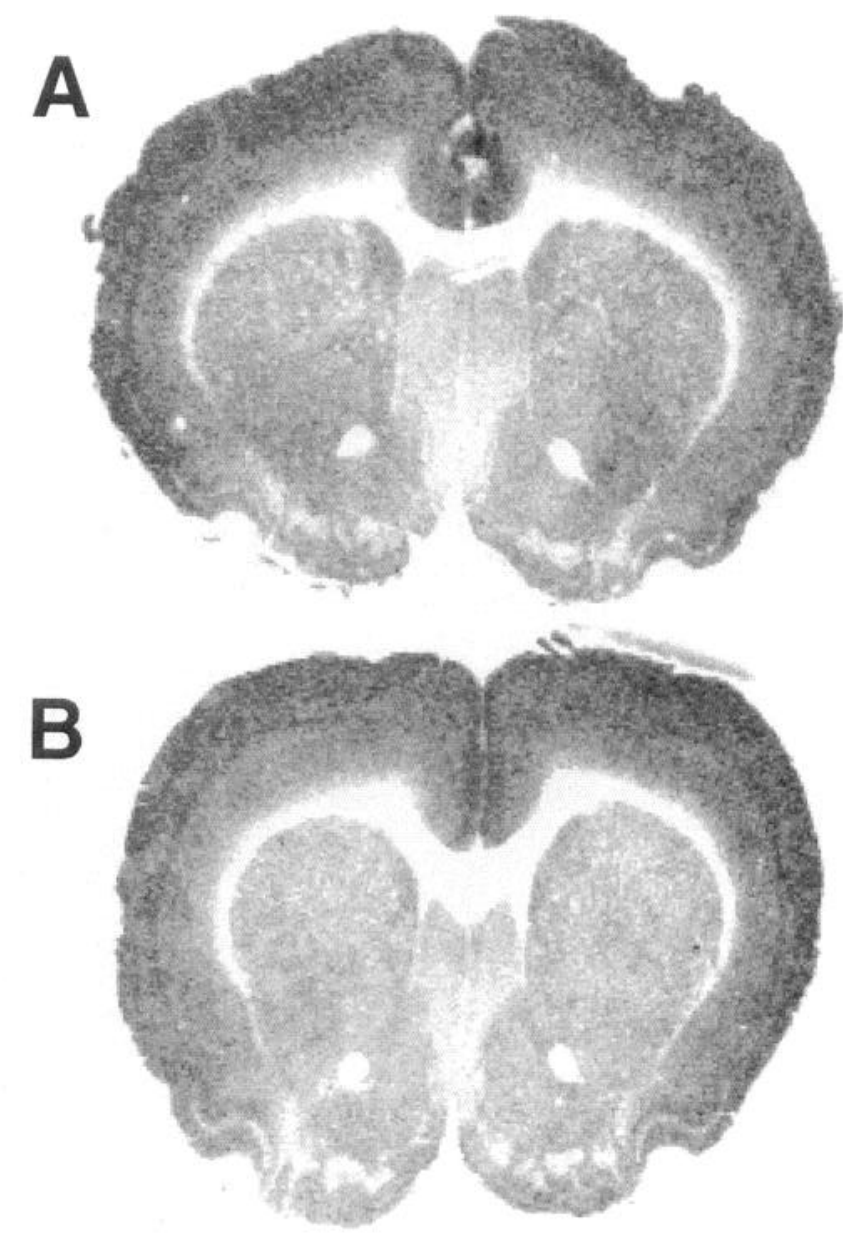

Figure 7. Digitized autoradiograms of ${ }^{3} \mathrm{H}-\mathrm{MK}-801$ binding in an unlesioned control brain $(A)$ and a brain with unilateral dopamine depletion $(B)$. Both autoradiographic images are from the same sheet of film and were digitized, processed, and printed identically. Note that there is reduced binding bilaterally in the striatum of the brain with unilateral dopamine depletion. Overall, there was a $31 \%$ decrease in striatal binding contralateral to the lesion $(p<0.0001)$, and a further $6 \%$ decrease ipsilateral to the lesion $(p<0.025)$. As shown in Figure 6 , the reduced binding contralateral to the lesion was restricted to striatum.

of extracellular glutamate and an increase in potassium-releasable glutamate in striatum (Yamamoto and Cooperman, 1993). There is also electrophysiological evidence that striatal dopamine depletion leads to increased spontaneous glutamate release in striatum (Calabresi et al., 1993). Further, as noted previously, the $\mathrm{SNr}$ becomes over active with dopamine depletion. Therefore, it is noteworthy that $\mathrm{SNr}$ stimulation leads to increased glutamate release in striatum (Girault et al., 1986). Such increases in glutamate levels and release might be expected to lead to receptor downregulation similar to that described here.

The mechanism by which unilateral dopamine depletion causes bilateral decreases in MK-801 binding is not known. Although some NMDA receptors may be located on nigrostriatal dopamine terminals (Krebs et al., 1991), the size of the crossed nigrostriatal pathway appears to be too small to account for the magnitude of the receptor changes (Altar et al., 1983). In contrast, unilateral electrical stimulation of $\mathrm{SNr}$ produces a bilateral 25-30\% increase in striatal glucose utilization (Savaki et al., 1983) that is similar in magnitude to the $30 \%$ reduction in NMDA receptors we found. Moreover, in animals with a uni- 
lateral dopamine depletion, chronic levodopa treatment leads to a bilateral upregulation of NMDA receptors (Weihmuller et al., 1993). The bilateral effect on striatum of unilateral $\mathrm{SNr}$ stimulation or dopamine depletion appears to be mediated through thalamic connections (Levine et al., 1977; Savaki et al., 1983; Girault et al., 1985). Thus, the presynaptic NMDA receptors located on dopaminergic terminals are not the predominate population of receptors undergoing regulation in these models. Instead, the effect appears to be mediated indirectly, perhaps by thalamocortical and corticostriatal pathways (Girault et al., 1986).

In summary, our results indicate not only that glutamatergic neurotransmission is altered with dopaminergic denervation of the striatum, but also that AMPA and NMDA receptor systems regulate differently in response to the loss of dopamine. The molecular basis of this differential receptor regulation is currently under investigation by means of in situ hybridization and immunocytochemistry with subunit-specific reagents.

\section{Implications for Parkinson's disease}

Based on what is known of basal ganglia circuitry, it appears that reducing neuronal activity in the basal ganglia output nuclei may provide a novel means of treating PD (Albin et al., 1989b; Crossman, 1989; Klockgether and Turski, 1989; DeLong, 1990). The fact that the glutamatergic STN plays an important functional role in regulating basal ganglia output suggests that it may be critically important in PD (Brotchie et al., 1991). DeLong and colleagues showed that small, axon-sparing lesions of STN produced a dramatic amelioration of parkinsonian signs in MPTP (1-methyl-4-phenyl-1,2,3,6-tetrahydropyridine)-treated monkeys (Bergman et al., 1990). Similar results have been obtained by Crossman's laboratory (Aziz et al., 1991). There is also a report of a patient with $\mathrm{PD}$ who developed a small hematoma involving the STN and had a remarkable improvement of his parkinsonism contralateral to the lesion (Sellal et al., 1992).

In our laboratory, we have been interested in the use of glutamate receptor antagonists to decrease basal ganglia output pharmacologically rather than surgically (Greenamyre and O'Brien, 1991; Greenamyre, 1993). We and others have shown that systemic administration of NBQX [2,3-dihydro-6-nitro-7sulfamoyl-benzo(f)quinoxaline], an AMPA receptor antagonist, has antiparkinsonian actions in rodents and primates (Klockgether et al., 1991; Löschmann et al., 1991). Similarly, NMDA receptor antagonists have antiparkinsonian effects in animal models of PD (Carlsson and Carlsson, 1989; Schmidt and Bubser, 1989; Klockgether and Turski, 1990; Morelli and DiChiara; 1990; Wüllner et al., 1992; Greenamyre et al., 1994). The results of the present study, and those of Klockgether and Turski (1993), suggest that the antiparkinsonian efficacy of AMPA and NMDA receptor antagonists may be due to actions at anatomical sites that are, at least in part, distinct. If this is the case, combinations of AMPA and NMDA receptor antagonists or nonselective antagonists may be particularly useful in the treatment of PD.

\section{References}

Albin RL, Aldrich JW, Young AB, Gilman S (1989a) Feline subthalamic nucleus neurons contain glutamate-like but not GABA-like or glycine-like immunoreactivity. Brain Res 491:185-188.

Albin RL, Young AB, Penney JB (1989b) The functional anatomy of basal ganglia disorders. Trends Neurosci 12:366-375.

Albin RL, Makowiec RL, Hollingsworth Z, Dure LS IV, Penney JB, Young AB (1992) Excitatory amino acid binding sites in the basal ganglia of the rat: a quantitative autoradiographic study. Neuroscience $46: 35-48$.

Altar A, Neve KA, Loughlin SE, Marshall JF, Fallon JH (1983) The crossed mesostriatal projection: neurochemistry and developmental response to lesion. Brain Res 279:1-8.

Aziz TZ, Peggs D, Sambrook MA, Crossman AR (1991) Lesion of the subthalamic nucleus for the alleviation of 1-methyl-4-phenyl1,2,3,6-tetrahydropyridine (MPTP)-induced parkinsonism in the primate. Movement Disord 4:288-292.

Bergman H, Wichmann T, DeLong M (1990) Reversal of experimental parkinsonism by lesions of the subthalamic nucleus. Science 249: 1436-1438.

Brotchie JM, Crossman AR (1991) D- $\left[{ }^{3} \mathrm{H}\right]$ aspartate and $\left[{ }^{14} \mathrm{C}\right] \mathrm{GABA}$ uptake in the basal ganglia of rats following lesions in the subthalamic region suggest a role for excitatory amino acid but not GABA-mediated transmission in subthalamic nucleus efferents. Exp Neurol 113: 171-181.

Brotchie JM, Mitchell IJ, Sambrook MA, Crossman AR (1991) Alleviation of parkinsonism by antagonism of excitatory amino acid transmission in the medial segment of the globus pallidus in rat and primate. Movement Disord 6:133-138.

Calabresi P, Mercuri NB, Sancessario G, Bernardi G (1993) Electrophysiology of dopamine-denervated striatal neurons. Implications for Parkinson's disease. Brain 116:433-452.

Carlsson M, Carlsson A (1989) The NMDA antagonist MK-801 causes marked locomotor stimulation in monoamine depleted mice. J Neural Transm 75:221-226.

Cha JH, Makowiec RL, Penney JB, Young AB (1992) Multiple states of rat brain $(R S)$ - $\alpha$-amino-3-hydroxy-5-methylisoxazole-4-propionic acid receptors as revealed by quantitative autoradiography. Mol Pharmacol 41:832-838.

Crossman AR (1989) Neural mechanisms in disorders of movement. Comp Biochem Physiol 93:141-149.

DeLong MR (1990) Primate models of movement disorders of basal ganglia origin. Trends Neurosci 13:281-285.

Girault JA, Savaki HE, Desban M, Glowinski J, Besson MJ (1985) Bilateral cerebral metabolic alterations following lesion of the ventromedial thalamic nucleus: mapping by the ${ }^{14} \mathrm{C}$-deoxyglucose method in conscious rats. J Comp Neurol 231:137-149.

Girault JA, Spampinato M, Desban M, Glowinski J, Besson MJ (1986) Enhancement of glutamate release in the rat striatum following electrical stimulation of the nigrothalamic pathway. Brain Res 374:362366.

Greenamyre JT (1993) Glutamate-dopamine interactions in the basal ganglia: relationship to Parkinson's disease. J Neural Transm 91:255269.

Greenamyre JT, O'Brien CF (1991) $N$-methyl-D-aspartate antagonists in the treatment of Parkinson's disease. Arch Neurol 48:977-981.

Greenamyre JT, Higgins DS, Eller RV (1992) Quantitative autoradiography of dihydrorotenone binding to complex I of the electron transport chain. J Neurochem 59:746-749.

Grcenamyre JT, Eller RV, Zhang Z, Ovadia A, Kurlan R, Gash DM (1994) Antiparkinsonian effects of remacemide, a glutamate antagonist, in rodent and primate models of Parkinson's disease. Ann Neurol 35:655-661.

Greene JG, Porter RHP, Eller RV, Greenamyre JT (1993) Inhibition of succinate dehydrogenase by malonic acid produces an "excitotoxic" lesion in rat striatum. J Neurochem 61:1151-1154.

Hovda DA, Chugani HT, Villablanca JR, Badie B, Sutton RL (1992) Maturation of cerebral oxidative metabolism in the cat: a cytochrome oxidase histochemistry study. J Cereb Blood Flow Metab 12:10391048 .

Kemp JM, Powell TP (1970) The cortico-striate projection in the monkey. Brain 93:525-546.

Kiernan JA (1990) Histological and histochemical methods, pp 263274. Oxford: Pergamon.

Klockgether T, Turski L (1989) Excitatory amino acids and the basal ganglia: implications for the therapy of Parkinson's disease. Trends Neurosci 12:285-286.

Klockgether T, Turski L (1990) NMDA antagonists potentiate antiparkinsonian actions of L-dopa in monoamine-depleted rats. Ann Neurol 28:539-536.

Klockgether T, Turski T (1993) Toward an understanding of the role of glutamate in experimental parkinsonism: agonist-sensitive sites in the basal ganglia. Ann Neurol 34:585-593. 
Klockgether T, Turski L, Honore T, Zhang Z, Gash DM, Kurlan R, Greenamyre JT (1991) The AMPA receptor antagonist NBQX has antiparkinsonian effects in monoamine-depleted rats and MPTPtreated monkeys. Ann Neurol 30:717-723.

Krebs M-O, Trovero F, Desban M, Gauchy C, Glowinski J, Kemel M-L (1991) Distinct presynaptic regulation of dopamine release through NMDA receptors in striosome- and matrix-enriched areas of the rat striatum. J Neurosci 11:1256-1262.

Levine MS, Hull CD, Buchwald NA, Garcia-Rill E, Heller A, Erinoff L (1977) The spontaneous firing patterns of forebrain neurons. III. Prevention of induced asymmetries in caudate neuronal firing patterns by unilateral thalamic lesions. Brain Res 131:215-225.

Löschmann PA, Lange KA, Kunow M, Rettig K-J, Jähnig P, Honoré T, Turski L, Wachtel H, Jenner P, Marsden CD (1991) Synergism of the AMPA-antagonist NBQX and the NMDA-antagonist CPP with I-dopa in models of Parkinson's disease. J Neural Transm 3:203213.

Marshall JF, Critchfield JW, Kozlowski MR (1981) Altered succinate dehydrogenase activity of basal ganglia following damage to mesotelencephalic dopaminergic projection. Brain Res 212:367-377.

Miller W, DeLong ML (1987) Altered tonic activity of neurons in the globus pallidus and subthalamic nucleus in the primate MPTP model of parkinsonism. In: The basal ganglia II (Carpenter MB, Jayaraman A, eds), pp 414-427. New York: Plenum.

Mitchell IJ, Clarke CE, Boyce S, Robertson RG, Peggs DE, Sambrook MA, Crossman AR (1989) Neural mechanisms underlying parkinsonian symptoms based upon regional uptake of 2-deoxyglucose in monkeys exposed to 1-methyl-1,2,3,6-tetrahydropyridine. Neuroscience 32:213-226.

Moore RY, Bhatnagar RK, Heller A (1971) Anatomical and chemical studies of a nigro-neostriatal projection in the cat. Brain Res 30:119135.

Morelli M, DiChiara G (1990) MK-801 potentiates dopaminergic $D_{1}$ but reduces $D_{2}$ responses in the 6-hydroxydopamine model of Parkinson's disease. Eur J Pharmacol 182:611-612.

Moriyoshi K, Masu M, Ishi T, Shigemoto R, Mizuno N, Nakanishi S (1991) Molecular cloning and characterization of the rat NMDA receptor. Nalure 354:31-37.

Price RH Jr, Hollingsworth Z, Young AB, Penney JB Jr (1993) Excitatory amino acid receptor regulation after subthalamic nucleus lesions in the rat. Brain Res 602:157-160.

Ricardo JA (1980) Efferent connections of the subthalamic region in the rat. I. The subthalamic nucleus of Luys. Brain Res 202:257-271.

Richfield EK (1991) Quantitative autoradiography of the dopamine uptake complex in rat brain using [ $\left.{ }^{3} \mathrm{H}\right] \mathrm{GBR}-12935$ : binding characteristics. Brain Res 540:1-13.
Robledo P, Feger J (1990) Excitatory influence of rat subthalamic nucleus to substantia nigra pars reticulata and the pallidal complex: electrophysiological data. Brain Res 518:47-54.

Sakurai SY, Cha JH, Penney JB, Young (1991) AB Regional distribution and properties of $\left[{ }^{3} \mathrm{H}\right] \mathrm{MK}-801$ binding sites determined by quantitative autoradiography in rat brain. Neuroscience 40:533-543.

Savaki H, Desban M, Glowinski J, Besson M-J (1983) Local cerebral glucose utilization in the rat. II. Effects of unilateral substantia nigra stimulation in conscious and in halothane-anesthetized animals. J Comp Neurol 213:46-65.

Savaki HE, Girault JA, Desban M, Glowinski J, Besson MJ (1985) Local cerebral metabolic effects induced by nigral stimulation following ventromedial thalamic lesions. II: Sensory motor, reticular and limbic systems. Brain Res Bull 14:287-296.

Schmidt WJ, Bubser M (1989) Anticataleptic effects of the $N$-methylD-aspartate antagonist MK-801 in rats. Pharmacol Biochem Behav 32:621-623.

Sellal F, Hirsch E, Lisovoski F, Mutschler V, Collard M, Marescaux C (1992) Contralateral disappearance of parkinsonian signs after subthalamic hematoma. Neurology 42:255-256.

Smith Y, Parent A (1989) Neurons of the subthalamic nucleus in primates display glutamate but not GABA immunoreactivity. Brain Res 453:353-356.

Sommer B, Keinanen K, Verdoorn TA, Wisden W, Burnashev N, Herb A, Kohler M, Takagi T, Sakmann B, Seeburg PH (1990) Flip and flop: a cell-specific functional switch in glutamate-operated channels of the CNS. Science 249:1580-1585.

Tallaksen-Greene SJ, Wiley RG, Albin RL (1992) Localization of striatal excitatory amino acid binding site subtypes to striatonigral projection neurons. Brain Res 594:165-170.

Weihmuller FB, O'Dell, SJ, Marshall JF (1993) Alterations in striatal glutamate receptors following 6-OHDA-induced damage to nigrostriatal dopamine neurons. Soc Neurosci Abstr 19:1678.

Wong-Riley MTT (1989) Cytochrome oxidase: an endogenous metabolic marker for neuronal activity. Trends Neurosci 12:94-101.

Wüllner U, Kupsch A, Arnold G, Renner P, Scheid C, Oertel W, Klockgether $T$ (1992) The competitive NMDA antagonist CGP40.116 enhances L-dopa response in MPTP-treated marmosets. Neuropharmacology 31:713-715.

Wüllner U, Brouillet E, Isacson O, Young AB, Penney JB (1993) Glutamate receptor binding sites in MPTP-treated mice. Exp Neurol 121 : 184-287.

Yamamoto BK, Cooperman MA (1993) Chronic haloperidol alters substantia nigra GABA and extracellular glutamate in striatum. Soc Neurosci Abstr 19:1623. 